\title{
CORRESPONDENCE
}

\section{Carbon emissions: the poorest forest dwellers could suffer}

Debate on the carbon-credit system known as REDD ('reducing emissions from deforestation and forest degradation') has focused on technical and methodological obstacles and on sourcing carbon finance. The impact of the system on the world's 350 million tropical forest dwellers calls for closer scrutiny.

Without careful planning, REDD stands to create large numbers of 'carbon refugees' as governments curb financially unrewarding deforesting activities such as those of small-scale agriculturalists and fuel-wood harvesters, who mostly pay no taxes on what they produce. Forest dwellers could become excluded from their means of subsistence to preserve carbon.

A similar situation has occurred during previous attempts to conserve tropical forests. Last year I worked in Liberia's forests bordering Ivory Coast, and heard of park guards in the Tai National Forest, a well-protected Ivorian biodiversity conservation area, shooting local hunters dead. I met Ivorian subsistence hunters, excluded from their ancestral lands, relocating to Liberia to maintain their livelihoods. The journal Conservation \& Society is investigating the possible displacement of thousands of people in Africa by biodiversity conservation projects.

The Centre for International Forestry Research has shown that forest-based sources of income generated by local communities are often rendered illegal by forest law. Crackdowns tend to target the poor, rather than the criminal networks behind the estimated $50 \%$ of global tropicaltimber exports that are illegal. A REDD-inspired redoubling of current efforts at law enforcement would further victimize forestdependent peoples.

Forest dwellers should be seen as an important part of the solution to deforestation. Evidence from 80 forest commons in 10 countries shows that community ownership, larger forest areas and a high degree of community autonomy in decision-making are all associated with both high carbon storage and livelihood benefits. Conversely, local users with insecure property rights extract resources at unsustainable rates (A. Chhatre and A. Agrawal Proc. Natl Acad. Sci. USA 106, 17667-17670; 2009).

Extending legal collective property rights to forest users over large areas, combined with forest-encroachment monitoring by independent scientists and local agencies, could reduce deforestation without human rights violations. This plan may substantially reduce deforestation by cutting off the supply of 'empty' land for outsiders to deforest.

There is good will on the ground for REDD to work, with safeguards. With transfers of US $\$ 10$ billion a year under discussion, the REDD agreement should ensure that at least 50\% of carbon payments go directly to forest dwellers, and that their property rights are assured. Otherwise, some of the world's most marginalized people will end up paying a high price for reducing carbon emissions.

Simon L. Lewis Earth and Biosphere Institute, School of Geography, University of Leeds, Leeds LS2 9JT, UK e-mail: s.l.lewis@leeds.ac.uk

\section{Carbon emissions: dry forests may be easier to manage}

You discuss in an Editorial (Nature $462,11 ; 2009)$ the promise of the emissions trading scheme REDD, whereby tropical countries will be rewarded for increased sequestration by forests. But it is important for negotiations to focus on the realities rather than on the ideal.

REDD countermeasures to tropical deforestation will affect food supplies and employment and will increase prices of forest products. They are likely to be contested by the powerful political forces that control logging, ranching, plantations and agricultural expansion in rainforests. It may therefore be premature to expect deforestation to be significantly reversed in the short term under REDD.

It may be easier to manage the politics and economics of emissions from degradation (that is, the thinning out rather than clearance of forest) in the world's dry forests and savanna woodlands. This type of degradation results primarily from the exploitation of forest by local communities as part of their livelihood. It has been tackled successfully in Nepal, India and Tanzania, for example, under programmes that promote community forest management.

Dry forests do not have the international status of the majestic Amazonian and Congo forests, and the dry-forest degradation option is relatively neglected in REDD debates. Although the carbon content of dry forests is considerably lower per hectare, more of their area is degraded because they are more densely populated.

Carbon losses may be more easily adressed because the commercial value of dry forests is lower, and their use is not so contested.

REDD should give more attention to dry forests. It should strengthen local communities' rights to manage the forests and to hold tenure there. Accounting the carbon savings would depend on proper estimates of local dryforest degradation rates (which are virtually unknown at present) and on devising ways to monitor the gradual increase in carbon stock resulting from community forest management.

Margaret Skutsch, Michael K. McCall CIGA, Universidad Nacional Autónoma de México, Morelia, CP 58190, México e-mail: mskutsch@ciga.unam.mx Jon C. Lovett CSTM, University of Twente, PO Box 217, 7500 AE Enschede, The Netherlands

\section{King Canute and the wisdom of forest conservation}

Copenhagen is where the world's nations are meeting this month to attend the all-important climate summit. It was also the capital of King Canute's empire and, by a quirk of history, it was Canute who drafted the first forestconservation legislation almost 1,000 years ago, as king of England (John Manwood

A Treatise of the Lawes of the Forest Societie of Stationers, London; 1615).

Manwood's book proclaims "Carta de Foresta, of King Canutus ... in the yeare of our Lord 1016" followed by the list of Canute's 34 Forest Laws. These were aimed at conserving forests at all costs, and especially their wildlife, with heavy penalties for offenders.

Law 28, for example, includes "No man may lay his hands upon the Kings demesne Woods without licence of the Verderor: for if he does, hee shal be aiudged guilty of the breach of the Kings free chase Royal."

Perhaps each nation attending the Copenhagen conference might agree to create its own new forest - thereby preserving endangered species, combating global warming and honouring Canute's apocryphal command to the seas to stop rising.

\section{Roger Short Faculty of Medicine,} Dentistry and Health Sciences, University of Melbourne, Victoria 3010, Australia e-mail: r.short@unimelb.edu.au

For more about limiting emissions, as the Copenhagen conference approaches, see pages 550, 555, 568 and 570 and http:// go.nature.com/sRCuKV.

Contributions may be submitted to correspondence@nature.com. Please see the Guide to Authors at go.nature.com/cMCHno. Science publishing issues are regularly featured at http://blogs.nature. com/nautilus. 